\title{
Article
}

\section{Work-rate of substitutes in elite soccer: A preliminary study}

Carling, C., Espié, V., Le Gall, F., Bloomfield, J., and Jullien, H.

Available at http://clok.uclan.ac.uk/12292/

Carling, C. ORCID: 0000-0002-7456-3493, Espié, V., Le Gall, F., Bloomfield, J., and Jullien, $H$. (2009) Work-rate of substitutes in elite soccer: A preliminary study. Journal of Science and Medicine in Sport, 13 (2). pp. 253-255. ISSN $1440-2440$

It is advisable to refer to the publisher's version if you intend to cite from the work. http://dx.doi.org/10.1016/j.jsams.2009.02.012

For more information about UCLan's research in this area go to

http://www.uclan.ac.uk/researchgroups/ and search for < name of research Group>.

For information about Research generally at UCLan please go to http://www.uclan.ac.uk/research/

All outputs in CLoK are protected by Intellectual Property Rights law, including Copyright law. Copyright, IPR and Moral Rights for the works on this site are retained by the individual authors and/or other copyright owners. Terms and conditions for use of this material are defined in the policies page.

\section{CLoK}

Central Lancashire online Knowledge www.clok.uclan.ac.uk

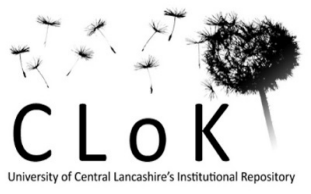


This is a pre-proof corrected manuscript, as accepted for publication, of an article published by Elsevier in Journal of Science and Medicine in Sport on $27^{\text {th }}$ June 2009, available online:

http://www.sciencedirect.com/science/article/pii/S144024400900098X

PLEASE REFER TO THE PUBLISHED VERSION FOR CITING PURPOSES

\section{Work-rate of substitutes in elite soccer: a preliminary study}

Authors: ${ }^{1}$ Christopher Carling, ${ }^{2}$ Vincent Espié, ${ }^{2}$ Franck Le Gall, ${ }^{3}$ Jonathan Bloomfield and ${ }^{4}$ Hugues Jullien

Institutions:

${ }^{1}$ Ecole des Métiers du Sport Professionnel, LOSC Lille Métropole Football Club, Domain de Luchin, Camphin-en-Pévèle, 59780, France;

${ }^{2}$ LOSC Lille Métropole Football Club, Domain de Luchin, Camphin-en-Pévèle, 59780, France;

${ }^{3}$ Sports Institute of Northern Ireland, University of Ulster, Jordanstown, Northern Ireland, BT37 OQB, UK;

${ }^{4}$ Faculté des Sciences du Sport, EA 3300: Conduites motrices et APS, Université de Picardie Jules Verne, Amiens, France).

Correspondance: Ecole des Métiers du Sport Professionnel, LOSC Lille Métropole Football Club, Centre de Formation, Domain de Luchin, Camphin-en-Pévèle, 59780, France.

Phone: 00.33.1.48910793

Fax: 00.33.1.48910793

Email: chris.carling@free.fr

Running head: Work-rate in elite soccer 


\begin{abstract}
The aim of this study was to investigate the work-rate of substitutes in professional soccer. A computerised player tracking system was used to assess the work-rates of second-half substitutes (11 midfielders and 14 forwards) in a French Ligue 1 club. Total distance, distance covered in five categories of movement intensity and recovery time between high-intensity efforts were evaluated. First- and second-half work-rates of the replaced players were compared. The performance of substitutes was compared to that of the players they replaced, to team-mates in the same position who remained on the pitch after the substitution and in relation to their habitual performances when starting games. No differences in work-rate between first- and second-halves were observed in all players who were substituted. In the second-half, a non-significant trend was observed in midfield substitutes who covered greater distances than the player they replaced whereas no differences were observed in forwards. Midfield substitutes covered a greater overall distance and distance at high-intensities $(p<0.01)$ and had a lower recovery time between high-intensity efforts $(p<0.01)$ compared to other midfield team-mates who remained on the pitch. Forwards covered less distance $(\mathrm{p}<0.01)$ in their first 10-minutes as a substitute compared to their habitual work-rate profile in the opening 10-minutes when starting matches while this finding was not observed in midfielders. These findings suggest that compared to midfield substitutes, forward substitutes did not utilise their full physical potential. Further investigation is warranted into the reasons behind this finding in order to optimise the work-rate contributions of forward substitutes.
\end{abstract}

Key terms: fatigue, football, substitutions, motion analysis 


\section{Introduction}

Research in elite soccer has identified the occurrence of a reduced work-rate between playing halves and in specific relation to high-intensity efforts towards the end of matches. ${ }^{1}$ There is a need therefore for countermeasures to fatigue and it has been suggested that the strategic use of substitute players during the second-half of matches could reduce the effects of fatigue across the team. ${ }^{2}$

However, only one study has examined the work-rate of substitutes in elite soccer. ${ }^{3}$ The work-rate of substitutes was shown to be superior to that of players in the starting 11 over the same time period. While this investigation had useful practical implications, there is need for further research into the physical contributions of replacements notably in comparison to players they replace and to their habitual performances when starting games.

In this preliminary study, we tested four hypotheses: (i) Players who are substituted demonstrate a reduction in work-rate. (ii) Substitutes have higher work-rates than the player they replace. (iii) Substitutes have higher work-rates in the time they played than other players in the same position. (iv) The work-rate of substitutes does not differentiate to that when starting games.

\section{Methods}

A multiple-camera player tracking system (AMISCO Pro, Sport-Universal Process, Nice, France) was used to analyse the work-rates of outfield substitute players belonging to a French $1^{\text {st }}$ Division professional soccer team during the 2007/2008 season. A total of 18 matches (15 home and 3 away games) were examined. Altogether, 11 midfield and 14 centreforward second-half substitutes who played a minimum of 10-minutes per game were included for analysis. Defenders were excluded due to a low number of substitutions.

The objective measures of work-rate performance selected for the analyses were classified into two categories: 1) Match distances covered including the overall distance and distance covered in five categories of movement intensity: $0-11 \mathrm{~km} / \mathrm{h}$ (walking and jogging); $11.1-14 \mathrm{~km} / \mathrm{h}$ (low-intensity running); $14.1-19 \mathrm{~km} / \mathrm{h}$ (moderate-intensity running); 19.1$23 \mathrm{~km} / \mathrm{h}$ (high-intensity running) and $>23.1 \mathrm{~km} / \mathrm{h}$ (sprinting). ${ }^{4}$ The absolute data were corrected to a minute-by-minute analysis of the distance covered in each category (distance divided by time played) to enable equal comparison of work-rate over the time period played by each player. ${ }^{1}$ 2) The average time spent in recovery between sprinting and high-intensity actions.

To test hypothesis 1 , the first- and second-half performance of the replaced players was compared. For hypothesis 2 , the performance over the time played by the substitute was compared to that during the second-half by the player he replaced. This analysis only included players who were directly substituted into their usual positional roles (i.e. a midfielder replaced another midfielder). Hypothesis 3 was tested by comparing the performance of the substitute to that of players in the same position who remained on the pitch over the same time period. The performance of forward substitutes could not be compared to that of other forwards as this team employed a 4-5-1 playing system and only one forward was ever present on the pitch. For hypothesis 4 , the performance of the substitute over the first tenminutes of competition (i.e. from 75 to $85 \mathrm{mins}$ ) was compared to his habitual performance over the opening ten-minutes of play when starting games. To determine the habitual workrate profile of the player, analyses were undertaken across five matches from the same season in which the player completed the entire 90-minutes.

Statistical analyses were performed using Bonferroni-adjusted paired t-tests (sameparticipant) or unpaired t-tests (between-participant) to test for differences in work-rate (SPSS Science Inc, Chicago, Ill). Bonferroni's adjustment was applied according to previously outlined procedures for objective measures of work-rate. ${ }^{5}$ Thus, an operational alpha level of $0.025(\mathrm{p}<0.05 / 2)$ was used. 


\section{Results}

No differences in work-rate between the first- and second-halves were observed in forwards and midfielders who were substituted (Table 1). Similarly, no differences were reported in work-rate in either forward or midfield substitutes compared to the players they replaced. However, the greater overall distance covered by the latter approached significance $(\mathrm{p}=0.044)$.

A greater minute-by-minute overall distance $(\mathrm{p}=0.006)$, distance in high-intensity activity $(\mathrm{p}=0.008)$ and a shorter recovery time between high-intensity efforts $(\mathrm{p}=0.003)$ was reported in midfield substitutes compared to other midfielders who remained on the pitch after the substitution.

Forwards covered less distance $(\mathrm{p}=0.004)$ as a substitute in their first 10 -minutes when compared to their habitual work-rate profile over the opening 10-minutes of matches while this was not observed in midfielders.

\section{Discussion}

In this preliminary study of work-rate in substitutes in elite soccer, several hypotheses were tested and are discussed in turn.

Firstly, no decline in work-rate in substituted players was observed. This result supports previous speculation in that the majority of substitutions are probably for tactical reasons rather than fatigue. ${ }^{2}$ Nevertheless, we suggest that further research on a larger sample of players combined with an analysis of technical performance is necessary to support the present findings.

Secondly, forward substitutes did not demonstrate a higher work-rate than the forward player they replaced whereas the trend, albeit non-significant, was for midfield substitutes to work harder. This observation in forward substitutes may have been influenced by factors such as the specific tactical requirements of their position. ${ }^{4}$ It may also be linked to an inability of these players to 'get into the game'. This latter suggestion may be confirmed by the dismissal of the fourth hypothesis in forwards as a significantly lower work-rate was observed in these players when introduced as substitutes compared to when starting matches. Further investigation is warranted into the reasons behind this finding in order to optimise the physical contributions of forward substitutes.

Thirdly, the overall work-rate and exercise at high-intensity in midfield substitutes was superior to that of players who had started the game, a result in accordance with previous findings in elite soccer. ${ }^{3}$ In addition, the work-rate of these players during their first tenminutes as a substitute was similar to their performances recorded during the opening tenminutes when starting matches. This finding is noteworthy as the highest intensity of game activities in elite soccer is generally observed in the opening 15-minute period of competition. ${ }^{1}$ Therefore, these observations on the physical contribution of midfield substitutes indicate the value of replacing players in this position when an increase in workrate is required.

\section{Practical implications}

The present findings are a first step in identifying and eventually optimising the workrate contributions of substitutes in elite soccer. 


\section{References}

1. Carling C, Bloomfield J., Nelsen L, et al. The role of motion analysis in elite soccer: Contemporary performance measurement techniques and work-rate data. Sports Med 2008;38:839-62.

2. Reilly T, Drust B, Clarke, N. Muscle fatigue during football match-play. Sports Med 2008;38:357-367.

3. Mohr M, Krustrup P, Bangsbo J. Match performance of high-standard soccer players with special reference to development of fatigue. J Sports Sci 2003;21:519-28.

4. Di Salvo V, Baron R, Tschan H, et al. Performance characteristics according to playing position in elite soccer. Int J Sports Med 2007;28:222-227.

5. Rampinini E, Coutts AJ, Castagna C, et al. Variation in top-level soccer match performance. Int J Sports Med, 2007;28:1018-24.

\section{Acknowledgements}

No financial assistance was obtained for this project.

\begin{tabular}{lllllll}
\hline & \multicolumn{2}{c}{$\begin{array}{c}\text { Replaced } \\
\text { midfielders }\end{array}$} & $\begin{array}{l}\text { Replacement } \\
\text { midfielders }\end{array}$ & \multicolumn{2}{c}{$\begin{array}{c}\text { Replaced } \\
\text { forwards }\end{array}$} & $\begin{array}{c}\text { Replacement } \\
\text { forwards }\end{array}$ \\
Variable & 1st half & 2nd half & 2nd half & 1st half & 2nd half & 2nd half \\
\hline Average time played (mins) & $45.5 \pm 0.2$ & $26.0 \pm 8.0$ & $22.5 \pm 8.1$ & $45 \pm 0.3$ & $23.0 \pm 7.1$ & $24.8 \pm 7.4$ \\
Total distance (m) & $129.3 \pm 3.6$ & $130.0 \pm 7.3$ & $136.6 \pm 9.1$ & $119.6 \pm 9.0$ & $121.7 \pm 10.2$ & $121.1 \pm 9.9$ \\
Sprint Distance (m) & $5.1 \pm 2.0$ & $5.5 \pm 3.9$ & $6.4 \pm 4.5$ & $5.1 \pm 2.0$ & $5.9 \pm 3.5$ & $5.3 \pm 2.4$ \\
$\quad$ Recovery time between efforts (s) & $296.2 \pm 108.3$ & $297.4 \pm 164.1$ & $315.5 \pm 198.9$ & $263.8 \pm 84.1$ & $282.3 \pm 126.4$ & $270.4 \pm 151.0$ \\
High-intensity distance (m) & $7.0 \pm 2.1$ & $7.3 \pm 3.1$ & $9.8 \pm 3.6$ & $6.7 \pm 1.5$ & $6.7 \pm 3.2$ & $6.7 \pm 1.7$ \\
$\quad$ Recovery time between efforts (s) & $117.8 \pm 34.8$ & $117.7 \pm 31.5$ & $95.1 \pm 38.5$ & $127 \pm 24.7$ & $125.6 \pm 44.0$ & $122.5 \pm 34.0$ \\
Moderate-intensity distance (m) & $23.6 \pm 2.4$ & $23.0 \pm 3.8$ & $28.6 \pm 3.9$ & $16.1 \pm 4.3$ & $17.5 \pm 5.5$ & $18.3 \pm 4.6$ \\
Low-intensity distance (m) & $21.7 \pm 2.8$ & $19.5 \pm 3.4$ & $21.8 \pm 4.5$ & $14.8 \pm 3.5$ & $16.7 \pm 5.5$ & $15.1 \pm 3.6$ \\
Walking/jogging distance (m) & $72.0 \pm 2.2$ & $74.1 \pm 3.6$ & $72.4 \pm 3.4$ & $76.2 \pm 4.4$ & $75.7 \pm 5.3$ & $75.3 \pm 3.4$ \\
\hline
\end{tabular}

Unless stated, data represent a minute-by-minute analysis of distance covered (all data are mean $\pm \mathrm{SD}$ ).

Table 1: First- versus second-half performance in substituted players and comparison with the second-half performance of their direct replacements. 